\title{
THE EFFECT OF TWO BULK-FILL RESIN COMPOSITES ON FRACTURE RESISTANCE OF ENDODONTICALLY TREATED TEETH
}

\begin{abstract}
Objectives: The aim of this study was to compare the effect of two commercially available bulk-fill restorative materials on the fracture resistance of endodontically treated human molar teeth.
\end{abstract}

Materials and methods: A total of 44 mandibular third molar were divided into four groups: Group 1; 4 mm thick bulk-fill fluid composite (SDR TM, Dentsply, Konstanz, Germany) was applied to the cavities. The restoration of the proximal walls and the occlusal region was completed with posterior composite (Valux Plus, 3M ESPE, St. Paul, MN, USA). Group 2; $4 \mathrm{~mm}$ thick fiber-resin reinforced bulk-fill composite (EverX Posterior; GC Corp., Japan) was placed in the cavities and the procedure in Group 1 was repeated. Group 3 (negative control group); no restoration was applied to the cavities. Group 4 (positive control group); comprised intact molar teeth without any treatment. The root canals were shaped using rotary instruments, irrigated with $\mathrm{NaOCl}$, and obturated. All samples were incubated in distilled water at $37^{\circ} \mathrm{C}$ for 1 week and then fracture strength test was performed. The values were recorded in Newton and the data were evaluated using Kruskal Wallis and Mann-Whitney U test.

Results: No statistically significant difference ( $p>0.05$ ) was observed between group 1,2 , and the positive control group. However, the bulk-fill fluid composite material showed higher fracture resistance than the fiber-resin reinforced composite material $(\mathrm{p}<0.05)$. The highest fracture resistance was observed in the positive control group. The fracture resistance of the negative control group was statistically lower than the other groups $(\mathrm{p}<0.05)$.

Conclusions: Both of the bulk-fill restorative materials in endodontically treated teeth showed similar fracture resistance to intact teeth. In addition, the clinical use of the bulk-fill fluid composites may be recommended because of their high fracture resistance and ease of application.

Keywords: Composite resin, fracture resistance, endodontics.
ORCID IDs of the authors:

Ö.T. 0000-0001-7835-0439

Ö.Ü. 0000-0001-9718-5790

1 Akdeniz University, Faculty of Dentistry, Endodontics Department, Antalya, Turkey

2 Akdeniz University, Faculty of Dentistry, Prosthetic Dentistry Department, Antalya, Turkey 


\section{INTRODUCTION}

Long-term success in endodontic treatment can be achieved through a durable and impermeable coronal restoration following an ideal root canal treatment. In these teeth, the loss of healthy tooth structure is usually considerable, and crown fracture following treatment can negatively affect their prognosis due to the secondary caries or unsuccessful restorations. Previous studies have demonstrated that the fragility of endodontically treated teeth was increased due to loss of tooth tissue resulting from the access cavity and root canal preparation rather than the changes in dentin tissue.

For many years, adhesive restorations were quite successful in protecting the remaining hard tissues in the endodontically treated teeth and increasing their fracture resistance. ${ }^{4,-6}$ Composite resins could be the material of choice to replace ceramic crowns due to their potential to mimic the dental anatomy, protect the periodontal structure, and provide a cost-effective, durable, and functional restoration of the tooth structure. The most important drawback of composite resin restorations is polymerization shrinkage. Prior to the placement of direct restorative materials; applying flowable composites having a low elastic modulus using a coating technique can reduce the shrinkage stress of composite resin. However, this procedure could be difficult, especially in the posterior teeth because it is time-consuming and isolation is not easy. The recently developed adhesive technologies have aimed at reducing the polymerization shrinkage and increasing the durability of one-stage (bulk-filling) restorations by adding glass or polyethylene fiber to the structure of composite materials..$^{3-6}$

The first bulk-fill composite introduced into the market was the SureFil SDR flow (SDR, Dentsply, Konstanz, Germany). It has advantages such as having a flowing consistency, allowing polymerization of $4-5 \mathrm{~mm}$ thick layers at a time, easy and short time of application. ${ }^{7,8}$ Another bulkfill composite material currently used is the fiberreinforced Ever X Posterior (EXP; GC Europe, Leuven, Belgium), which is a successful product with many proven mechanical properties. ${ }^{9,10}$ There has been increasing interest in this material due to the reports of its superior durability, especially against pressure.

The aim of this study was to compare the effect of two commercially available bulk-fill restorative materials on the fracture resistance of endodontically treated human molar teeth. The null hypothesis was that there would be no difference between the materials used regarding the fracture resistance of root-filled teeth.

\section{MATERIALS AND METHODS}

In this study, 44 non-carious human third molar teeth extracted due to periodontal reasons, were used. The study was approved by the Akdeniz University Faculty of Medicine Ethics committee No:2012-KAFK-20/238. The extracted teeth were stored in distilled water at $+4^{\circ} \mathrm{C}$ until the study was performed. The specimens were examined under $2.5 \mathrm{X}$ magnification with loupes in order to identify the teeth with root caries, broken and cracked teeth, teeth with oblique roots or open apices. The teeth with a mesiodistal width of $11 \pm 1 \mathrm{~mm}$ and a buccolingual width of $10 \pm 1 \mathrm{~mm}$ were included in the study. Teeth that meet the criteria of this study were randomly divided into 4 groups with 11 specimens per group. The schematic distribution of the groups is shown in Figure 1.

$\begin{array}{cl}\begin{array}{c}\text { Grup 1 } \\ \text { (SDR) }\end{array} & \text { Inlay cavity } \\ & 4 \mathrm{~mm} \text { SDR } \\ & \text { posterior composite } \\ \text { Grup 2 } & \text { Inlay Cavity } \\ \text { (EverX) } & 4 \mathrm{~mm} \text { EverX } \\ & \text { Posterior composite } \\ \text { Grup 3 } & \text { Inlay cavity } \\ \text { (positive control) } & \text { No restoration } \\ & \\ \text { Grup 4 } & \text { No inlay cavity } \\ \text { (negative control) } & \text { No restoration }\end{array}$

Figure 1. Schematic representation of the groups

Class II mesio-occlusal-distal (MOD) cavities were prepared in all samples except the Group 4. Group 4 was designated as the positive control group and the tooth specimens in this group were 
left untreated and stored at $+4 \mathrm{C}$ until the fracture resistance test. The buccolingual width of each cavity was measured with a digital caliper (Mitutoyo, Corp., Kawasaki, Japan), and standardized to be half of the intercuspal distance and it included the pulp chamber. For root canal treatment, the access cavities were prepared by using a diamond bur and fissure burs under water cooling. The working length of the root canals was determined with a \# $15 \mathrm{~K}$ type file (Mani Inc, Tochigi, Japan). The canals were shaped using the Protaper Next (PTN, Dentsply Maillefer, Switzerland) rotary file system. The mesial canals were extended up to $\mathrm{X} 2$ and the distal canals up to $\mathrm{X} 3$ file. During extension, the canals were irrigated with $2 \mathrm{ml}$ of $2.5 \% \mathrm{NaOCl}$ between each file. The last irrigation protocol included $2 \mathrm{ml} \mathrm{17 \%} \mathrm{long}$ version (EDTA) and distilled water, respectively. After the root canals were dried with paper points, the root canals were filled using gutta-percha (PTN, Dentsply Maillefer, Switzerland) and resinbased root canal sealer (2Seal, VDW, Munich, Germany) using the single cone method.

In Group 1, Clearfil SE bond (Kuraray Co, Osaka, Japan) was applied to the cavity in accordance with the manufacturers' recommendations and polymerized for $20 \mathrm{light} / \mathrm{sec}$ (Valo, Ultradent, USA). The mesial and distal margins of the tooth specimens, shaped using metal matrix bands, were restored with a posterior composite (Valux Plus, 3M ESPE, St. Paul, MN, USA ), and a Class I cavity form was created. SDR was placed at a thickness of approximately $4 \mathrm{~mm}$ at a time, corresponding to $1.5-2 \mathrm{~mm}$ below the occlusal level, and the was polymerized for 40 seconds with dental light curing unit (Valo, Ultradent, South Jordan, USA). The remaining cavity was restored with the posterior composite resin. Following Class I cavity preparations similar to Group 1, EXP was placed in a single phase at a depth of $4 \mathrm{~mm}$ to the specimens of Group 2 and polymerized for 40 seconds. The remaining cavity space was restored with posterior composite resin. No restoration was applied on Group 3 specimens. Following these procedures, polishing was performed under water cooling using aluminum oxide coated discs (Soflex, 3M ESPE, MN, USA). The root surfaces of the restored tooth specimens were covered with a thin wax layer up to $1 \mathrm{~mm}$ below the cemento-enamel junction in order to mimic the periodontal ligament. The specimens were then placed vertically in a self-hardening acrylic mold (Imicryl, Turkey) in cylinder blocks of $4.5 \times 2.5 \mathrm{~cm}$ up to $1 \mathrm{~mm}$ lower the level of enamel cement combination.

After being stored in the incubator at $37^{\circ} \mathrm{C}$ for a week at $100 \%$ humidity, the teeth were inserted to the universal test device (AG-5 kNG, Shimadzu, Tokyo, Japan). At the point corresponding to the central fossa of the teeth, fracture strength test was performed by applying parallel forces to the long axis of the tooth at a speed of $1 \mathrm{~mm} / \mathrm{min}$. The forces at the moment of fracture were recorded as Newton (N).

\section{Statistical Analysis}

All of the statistical analyses were conducted using SPSS 19 software (SPSS Inc., Chicago, IL USA). The data were assessed by using Kruskal Wallis and Mann-Whitney $U$ tests. The level of significance was determined at $\mathrm{p}<0.05$.

\section{RESULTS}

No statistically significant difference was found among the Group 1, Group 2 and the positive control group (Group 4) ( $p>0.05$ ). However, the bulk-fill flowable composite material showed higher fracture resistance than the fiber reinforced composite material. The highest fracture resistance was observed in the positive control group. The fracture resistance of the negative control group was statistically lower than all the other groups $(p<0.05)$. The results are shown in Table I. 
Table 1. Fracture strenght of the groups (Newton, Mean \pm SD)

\begin{tabular}{lll}
\hline Group & N & Mean \pm SD \\
\hline Group 1 (SDR) & 11 & $2207.95 \pm 431.85^{\mathrm{a}}$ \\
Group 2 (EverX) & 11 & $2064.13 \pm 415.67^{\mathrm{a}}$ \\
Group 3 (negative control) & 11 & $729.03 \pm 161.54^{\mathrm{b}}$ \\
Group 4 (positive control) & 11 & $2417.11 \pm 266.21^{\mathrm{a}}$ \\
\hline
\end{tabular}

SD: Standart deviation. Same superscript letter indicates statistically similar values $(\mathrm{p}>0.05)$

(Kruskal Wallis and Mann Whitney U test)

\section{DISCUSSION}

The most important factor affecting the clinical success of endodontically treated teeth is the remaining coronal tooth tissue. In order to achieve long-term success after treatment, apart from restoring the tooth function, the retention and durability of restoration should also be enhanced. The choice of restorative material and the restoration technique are very important to increase the durability of the teeth against fracture. In many studies it was shown that fiber-reinforced composites have many advantages as better adhesion of composite luting agent to the fiber, physiological stiffness of the denture framework made of fiber, and a better elastic modulus match between fiber-reinforced composite restoration and dentin/enamel. ${ }^{9,10,11}$ In this study both bulk fill composite restorations showed fracture resistance values similar to intact teeth.

The preparation of cavity access in posterior teeth having a MOD cavity without marginal support or with significant structural loss may cause loss of resistance. ${ }^{12}$ The recently developed bulk-fill composites can replace the layering technique due to the application of a single mass of $4 \mathrm{~mm}$ thickness. ${ }^{13}$ In our study, when compared to the positive control group, cavity preparation in the negative control group significantly reduced the fracture strength of the dental specimens $(\mathrm{p}<0.05)$. The findings are consistent with previous studies. ${ }^{5,14}$

In the teeth with considerably decreased fracture resistance due to cavity preparation, completing the canal treatment and coronal restoration with the most suitable material in one session significantly increases the success. EXP, a fiber-reinforced bulk-fill composite, has recently become a preferred material for endodontically treated posterior teeth with large cavities. EXP is designed as a single-layer substructure material consisting $7.2 \%$ short fibers by volume.A conventional composite resin restoration is further required. EXP has more advanced fracture strength, bending resistance, and load-bearing capability than conventional composites. ${ }^{15,16}$ The reinforcing effect of EXP is based on versatile, discontinuous short E-glass fibers that prevent crack propagation in a semi-intertwined polymer matrix. These fibers can provide an isotropic reinforcing effect, since each fiber acts as a crack stopper and transfers stress from the polymer matrix to stronger fibers. ${ }^{15}$

In this study, there was no statistically significant difference between the positive control group and the EXP group. The fracture strength values were found to be similar to a healthy tooth. The reason for fracture resistance could be because of glass fibers which increase the material stiffness and resistance to bending forces. This result is important because it provides safe clinical use. SDR that is the other composite resin used in our study, was the first bulk-fill composite. It contains a photoactive group in the modified urethane dimethacrylate resin. This structure allows the light, which is required for the polymerization, to reach the deeper layers of the composite. This enables the application of the composite at a thickness of 3-4 mm at a time. ${ }^{17,18}$ In this study, no statistically significant difference was observed among the fracture strength values of SDR, EXP, and the positive control group. These findings are consistent with those in previous studies. ${ }^{7}$ In another study, EXP showed better results than SDR in terms of compressive and flexural strength 
values except hardness. In this study, the higher fracture resistance of SDR than EXP, can be explained by higher nano hardness values. ${ }^{19}$

The chemical solutions, especially $\mathrm{NaOCl}$, used in the root canal treatment may cause mechanical changes in the dentine tissue residues and increase the risk of crown fracture. In a recent study, it has been demonstrated that the irrigation protocol with $5.25 \%$ of $\mathrm{NaOCl}$ significantly reduces the crown fracture resistance..$^{20,21}$ Thus, the choice of materials that are close to the physical and mechanical characteristics of healthy tooth tissue is very important for endodontically treated teeth. In this context, both bulk-fill composite materials used as upper restorations, have demonstrated fracture resistance values close to that of a healthy tooth. As far as the ease of clinical applications is concerned, SDR, through its flowable feature, may provide the clinicians with advantages.

\section{CONCLUSIONS}

Within the limits of this study, our findings demonstrate that the bulk-fill composites provide ease of use, decrease the time of application of the upper restoration, and increase the fracture strength of root canal treated teeth. It is important that the findings of this in vitro study should be supported with in vivo studies.

\section{ACKNOWLEDGEMENTS}

None

\section{CONFLICT OF INTEREST STATEMENT}

Authors declare no conflicts of interest.

\section{İki Güncel Bulk-Fill Rezin Kompozitin Endodontik Tedavili Dişerin Kurılma Direnci Üzerine Etkisi $\ddot{O} Z$}

Amaç: İki güncel bulk-fill özellikte restoratif materyalin, endodontik tedavili insan molar dişlerinin kirlma direnci üzerine etkisini karşılaştırmakttr. Materyal ve Metod: Bu çalışmada 44 adet üçüncü molar diş seçilerek rastgele 4 gruba ayrıldı $(n=11)$. Grup l'de kavitelere $4 \mathrm{~mm}$ kalınlı̆ı̆nda bulk-fill akışkan kompozit materyal (SDR ${ }^{\mathrm{TM}}$, Dentsply) yerleştirildikten sonra proksimal duvarlara rezin kompozit (Valux Plus, 3M ESPE) uygulandr ve kalan okluzal bölgenin de restorasyonu yapılarak işlem tamamlandl. Grup 2'de kavitelere 4 mm kalınlığında fiberle güçlendirilmiş bulk- fill kompozit materyal (EverX Posterior; GC) yerleştirildikten sonra 1. gruptaki işlemlerin aynısı uygulandl. Grup 3'de (negatif kontrol grubu) kavitelere herhangi bir restorasyon uygulanmadl. Grup 4'de (pozitif kontrol grubu) tamamen sağlam dişler kullanıldı. Diş kök kanalları NaOCl ile irrige edilerek döner aletlerle şekillendi ve güta perka ile dolduruldu. Tüm örnekler $37^{\circ} \mathrm{de} 1$ hafta süreyle inkübatörde bekletildikten sonra kirlma dayanımı testi gerçekleştirildi. Newton olarak kaydedilen veriler Kruskal Wallis ve Mann-Whitney U istatistiksel analizi ile değerlendirildi. Bulgular: Grup 1, Grup 2 ve Grup 4 (pozitif kontrol grubu) arasinda istatistiksel farklllik gözlenmedi ( $p>0.05)$. Bununla birlikte bulk-fill akuşkan kompozit materyali, fiber-rezinle güçlendirilmiş kompozit materyalinden daha yüksek kirlma direnci göstermiştir $(p<0.05)$. En yüksek krrlma dayanımı pozitif kontrol grubunda görülürken, negatif kontrol grubunun kırılma dayanımı diğer gruplardan istatistik olarak anlamlı ölçüde düşük bulunmuştur $(p<0.05)$. Sonuç: Her iki güncel bulk-fill restoratif materyali de endodontik tedavili dişlerde benzer kurlma direnci göstermiştir. Bunun yanı sira bulk-fill akışkan kompozitlerin daha yüksek kirllma direnci sağlaması ve uygulama kolayllğından dolayı klinik kullanımı tavsiye edilebilir. Anahtar Kelimeler: Kompozit rezin, kirlma dayanımı, endodonti.

\section{REFERENCES}

1. Sathorn C, Palamara JE, Palamara D, Messer HH. Effect of root canal size and external root surface morphology on fracture susceptibility and pattern: A finite element analysis. J Endod 2005; 31: 288-292.

2. De V Habekost L, Camacho GB, Azevedo EC, Demarco FF. Fracture resistance of thermal cycled and endodontically treated premolars with adhesive restorations. J Prosthet Dent 2007; 98: 186-192.

3. Taha NA, Palamara JE, and Messer HH. Fracture strength and fracture patterns of root filled teeth restored with direct resin restorations. J Dent 2011; 39: 527-535. 4. Hürmüzlü F, Kiremitçi A, Serper A, Altundaşar E, Siso SH. Fracture resistance of endodontically treated premolars restored with ormocer and packable composite. J Endod 2003; 29: 838-840.

5. Sengun A, Cobankara FK, and Orucoglu H. Effect of a new restoration technique on fracture resistance of endodontically treated teeth. Dent Traumatol 2008; 24: 214-219. 
6. Eapen AM, Amirtharaj LV, Sanjeev K, Mahalaxmi S. Fracture Resistance of Endodontically Treated Teeth Restored with 2 Different Fiber-reinforced Composite and 2 Conventional Composite Resin Core Buildup Materials: An In Vitro Study. J Endod 2017; 43: 14991504.

7. Atalay C, Yazici AR, Horuztepe A, Nagas E, Ertan A, Ozgunaltay G. Fracture Resistance of Endodontically Treated Teeth Restored With Bulk Fill, Bulk Fill Flowable, Fiber-reinforced, and Conventional Resin Composite. Oper Dent 2016; 41: 131-140.

8. Özler M, Öter Ş, and Korkmaz A. Ozon Gazının Tıbbi Amaçlı Kullanılması. TAF Preventive Medicine Bulletin 2009; 8: 59-64.

9. Bijelic-Donova J, Garoushi S, Vallittu PK, Lassila LV. Mechanical properties, fracture resistance, and fatigue limits of short fiber reinforced dental composite resin. JProsthet Dent 2016; 115: 95-102.

10. Abouelleil H, Pradelle N, Villat C, Attik N, Colon P, Grosgogeat B.Comparison of mechanical properties of a new fiber reinforced composite and bulk filling composites. Restor Dent Endod 2015; 40: 262-270.

11.Izgi AD, Eskimez S, Kale E, Değer Y. Directly fabricated inlay-retained glass- and polyethylene fiberreinforced composite fixed dental prostheses in posterior single missing teeth: a short-term clinical observation. J Adhes Dent 2011; 13: 383-391.

12. Isufi $A$, Plotino $G$, Grande $N M$, Ioppolo $P$, Testarelli L, Bedini R, Al-Sudani D, Gambarini G. Fracture resistance of endodontically treated teeth restored with a bulkfill flowable material and a resin composite. Ann Stomatol 2016; 7: 4-10.
13.Kanık Ö, Türkün LS. Restoratif Cam Iyonomer Simanlarda Güncel Yaklaşımlar. EÜ Dişhek Fak Derg 2016; 37: 54-65.

14. Kaval ME, Pişkin B, Yapar DG, Sarıkanat M. Endodontik Tedavili Dişlerde Koronal Restorasyonun Örgü Fiber İle Güçlendirilmesinin Kırılma Dayanımına Etkisi. EÜ Dişhek Fak Derg 2014; 35: 37-40.

15.Sengun A, Çobankara FK, Orucoğlu H. Effect of a new restoration technique on fracture resistance of endodontically treated teeth. Dental Traumatology 2008; 24: 214-219.

16. Garoushi S, Vallittu PK, and Lassila L, Mechanical Properties and Wear of Five Commercial FibreReinforced Filling Materials. Chin J Dent Res 2017; 20: 137-143.

17. Garoushi S, Gargoum A, Vallittu PK, Lassila L. Short fiber-reinforced composite restorations: A review of the current literature. J Investig Clin Dent 2018; 9: e12330.

18.Garcia D, Yaman P, Dennison J, Neiva G. Polymerization shrinkage and depth of cure of bulk fill flowable composite resins. Oper Dent 2014; 39: 441448.

19. Meenakumari C1, Bhat KM2, Bansal R3, Singh N1. Evaluation of Mechanical Properties of Newer Nanoposterior Restorative Resin Composites: An In vitro Study. Contemp Clin Dent. 2018;9: 142-146.

20.Çelik Ç. Güncel Kompozit Rezin Sistemler. Turkiye Klinikleri J Restor Dent-Special Topics 2017; 3: 128137.

21.Baechtold M, da Cunha L, Souza E, Gabardo M, de Oliveira K, Baratto-Filho F, Leonardi D, Effect of Endodontic Irrigation Protocols on Crown Fracture Resistance. J Contemp Dent Pract 2018; 19: 768-772. 